FACTA UNIVERSITATIS

Series: Teaching, Learning and Teacher Education Vol. 1, No 2, 2017, pp. 161 - 172

https://doi.org/10.22190/FUTLTE1702161M

Review article

\title{
THE ROLE OF TEACHERS AND SCHOOL PROFESSIONAL TEAMS IN PREVENTION OF DIGITAL VIOLENCE
}

UDC 316.624-057.874:004.738.5

\section{Lela Milošević Radulović, Suzana Marković Krstić}

University of Niš, Faculty of Philosophy, Department of Sociology, Serbia

\begin{abstract}
The paper discusses the role of teachers and school professional teams in prevention of digital violence in order to increase the safety of students while using the information and communication technology. The school as the center of the educational process can, with its continuous action, indicate the possible risks in the functioning and usage of information and communication technology, as well as other key factors in prevention of digital violent behavior and social intervention when violence occurs. The social reaction to digital violence implies the application of an active school education strategy that involves acquiring knowledge about the risks and risk behaviors and developing the responsibility of an individual when using digital technologies, then a strategy of action when an individual is exposed to some form of digital violence and sanctions for those who violate the rules. In recent years, scientists and experts have been involved in theoretical and empirical researches in the field of digital violence in order to gain knowledge and raise awareness about the dangers that threaten in the virtual environment. Such initiatives can significantly contribute to the intensification of the educational activities of the school (teachers and professional teams) by pointing to their indispensable role and importance in designing adequate preventive strategies for solving this significant social problem.
\end{abstract}

Key words: digital violence, prevention, teacher, school professional team, active educational strategy.

\section{INTRODUCTION}

The contemporary global social system represents a constant strengthening of interconnection through new information and communication technologies. The Internet as a medium and communication technology is becoming a widespread field of scientific research because, as D. Ristic and his associates point out, the Internet is much more than

Received January 03, 2017/Accepted January12, 2017

Corresponding author: Lela Milošević Radulović

Faculty of Philosophy, Universityof Niš, Ćirila i Metodija 2, 18000 Niš, Serbia

Phone: +38118 514-312•E-mail: lela.milosevic.radulovic@gmail.com 
a simple technology network. It is an „open network“ or a set of dynamic and complex technological and social practices. Definitions of the Internet mainly emphasize its technical and technological aspects, while visibly neglecting the fact that without coordinated social activities of its use it would not function (more Ristić, 2014, 26). In addition to the Internet, new media, or digital technologies, include mobile phones, computer games, and so on.

Nowadays, digital technologies are integral part of chilren's growing up from their earliest age due to their wide presence in all areas of personal and social life. There are many advantages and possibilities of using digital technologies, both in terms of learning and in terms of free activities: the ability to acquire new knowledge, literature review, quick access to various interesting and educational information, quick and easy communication with people from different parts of the world, exchange of experiences and opinions with people of similar interests and problems, different sources of entertainment, the possibility of buying different products and similar. However, despite all the advantages, digital technologies bring a number of hazards and risks. It is very difficult to establish the rules of behavior in order to ensure the safety of users in communication via digital technologies. Hence these technologies should be seen as a useful treasure house of knowledge, data and a number of possibilities which should be approached with great responsibility. Insufficiently developed security awareness can make these technologies a source of numerous dangers.

In recent years violence has occured more often through digital technologies - it's called digital violence. Therefore, in scientific circles, more and more initiatives are being taken to investigate this significant social problem in order to raise awareness, especially with children, of the threatening dangers, as well as to design preventive strategies. Accordingly, the focus of this paper is to consider the role of teachers and professional teams in the prevention of digital violence among primary school students.

\section{Digital Violence}

D. Olveus (D. Olweus, 1998) defines violence as a special form of aggression, with the dominant individual (bully) continuously behaving aggressively towards a less dominant individual (victim). When distinguishing between the terms violence and abuse, the criterion of frequency of the violent behavior is used. Abuse includes a set of intentional negative procedures that are long-lasting and targeted at the same person or group. Abuse is when the violent behavior is carried out against one person at least 2-3 times a month and more often. Negative actions include physical and/or psychological violence and isolation, while the relation between the abuser and the victim always implies a relation based on the power - powerlessness attitudes.

There are various forms of violence: physical, psychological (emotional), social, digital, sexual violence, neglect, abuse and exploitation. All forms of violence mutually intertwine, so there are no clear boundaries between them. Lately, beside other forms of violence, special attention of the public and experts has been paid to digital violence.

Cyberbullying involves the use of digital technology (the Internet and mobile phones) for the purpose of injuring and harassing other people. Other terms for this form of violence can be found in the literature, such as electronic violence, online violence, cyber violence and similar. Digital violence can be manifested in various ways: sending messages via a 
mobile phone or the Internet, or any kind of communication activities using cyber technology that manifests itself in the form of malicious and threatening texts or video messages, photos or calls. We're talking about the situations when someone uses digital devices to introduce themselves with a false name or to threaten others (by disturbing, recording with a mobile phone or a video camera, and publicly uploading images). Perpetrators or victims of this kind of violence can be both individuals and entire groups. It most often occurs with children and young people, but it is also present among adults. Examples of digital violence are numerous: threats, humiliation and teasing, spreading rumors and lies about someone, sending inappropriate content, identity theft, and so on. Aggravating circumstances are that the content can easily be shared with others and that a large number of people can see it for a short time.

Children often misuse the Internet by giving false information about their age. This is confirmed by the research carried out at the end of 2012 (Popadić and Kuzmanović, 2013). The results of this study showed that even half of the 10-year-olds surveyed have a profile on a social network (mainly on Facebook) by providing false information about their age. The question that often arises is whether digital violence is more dangerous than violence that occurs in real life. Digital violence can indeed be more dangerous than violence that occurs in the real world precisely because, due to the anonymity of the executor, there is less fear of discovery and punishment. Besides, this form of violence can be commited at any time and from any place, even when we are not personally present.

Violence, abuse and neglect are explicitly forbidden by the Law on the Foundations of the Education System (2017, Article 111), whereby the prohibition is clearly and unequivocally emphasized, and violence, abuse and neglect are precisely determined and defined. Violence and abuse involves every form once done or repeated verbal or nonverbal behavior which results in a real or potential threat to health, development and dignity of the child, pupil and adult, while digital violence and abuse involve the misuse of information and communication technologies that can result in a violation of someone's personality and endangering one's dignity, and it is accomplished by sending emails, sms, mms, through a website, chatting, joining in forums, social networks and other forms of digital communication. This law also obliges the institution to immediately submit a report to the competent authority in the case of violence, abuse or neglect.

\section{The Results of Some Previous Researches on Digital Violence}

Digital violence is often the subject of scientific research in the world. In recent years it has been explored in our country. Ž. Spalević states that the reasons for violence in the cyber space are the desire and the need to establish power over others, boredom or a desire for „entertainment“ or response to violence by violence (Spalević, 2013, 723). Recognizing the problem of digital violence and perceiving determinants that affect its occurrence can significantly contribute to adequate social prevention.

A survey conducted on a sample of 5,000 female students in South Korea showed that as many as $36 \%$ of respondents were victims of digital violence in 2012 . For this reason, they felt lonely, helpless and less valuable. Also, British Telegraph reporters found out the information that about $40 \%$ of women were victims of abuse after accepted on-line relationships, and $20 \%$ abusers continued to persecute victims through social networks Facebook, MySpace, Twitter (Kowalski , Limber, Agatston, 2010, according to Spalević, 
$2013,723)$. Norwegian researchers conducted a survey on a sample of 4,700 respondents and found that psychological violence with anonymous sms messages has a particularly negative impact on girls. According to the report, a girl experienced nightmares because of these scary messages which harassed her so much that she thought about suicide. One of her peers, instead of birthday greetings, received 25 malicious text messages that upset her so much that she did not dare to go to school anymore and needed psycho therapy (Stanić, 2007, according to Škrlec, Buljan Flander and Kralj, 2010, 666).

One of the important research on this topic in our country is a survey conducted at the end of 2012, organized by the Ministry of Education, Science and Technological Development, UNICEF and Telenor, within the project „Stop Digital Violence“. The focus of this research was the use of digital technology and risks when using digital technology among primary and secondary school students in Serbia. The research involved 3786 pupils (2272 from primary and 1514 from secondary schools), 3078 parents and 1,379 teachers. The results of the survey show that the most prevalent form of risky behaviour among primary and secondary school students is the acceptance of friendship requests on numerous social networks from people who they have never met in real life before. It is also risky to communicate via chat rooms with complete strangers, and what is particularly alarming is that many young people are ready to reveal their personal information to them. One of the findings of this research is that with the increase in students' inclination to risky behavior, increases the frequency of digital violence (in this case, students are more often involved in digital violence, either as victims, attackers or witnesses of violence) (Popadić and Kuzmanović, 2013).

A survey on digital violence was conducted in 2015 in Čačak (Pešić, 2015) in a much smaller sample (98 pupils of the eighth grade from two primary schools), but regardless of the small sample, it is certainly worthwhile to mention some of the findings. It was investigated how many students use digital technology, whether they are exposed to the risks of digital communication, to what extent they are involved in different forms of digital violence, and how they reacte if something like that happen to them. Recommendations to pupils, teachers and parents on how to prevent digital violence are an integral part of the work and an important step in the joint action of all actors in the prevention of digital violence. Basic research findings showed that most respondents use the Internet every day or almost every day, whether via a mobile phone or a computer, and that they usually visit social networks, watch videos, movies and series, while they rarely use the Internet to read and write blogs or visit a forum. Most students have a profile on a social network that they regularly use and they are exposed to harassment. In such situations, they usually first talk to a friend, brother or sister about it. The most common risks of using digital technology are the acceptance of a friendship request from people who they do not know from the real world, chatting with them, and leaving personal information. Particularly important is the fact that half of the surveyed students do not know how to block a person they do not want to receive e-mails from. It is also important that students get information about the risks on the Internet via the Internet itself, and that they talk about it mostly with their parents, which shows the insufficient role of teachers and the school in developing security culture. Such results also confirm that parents' education on the risks of using digital technologies is very important. It is also worth mentioning that a large number of Internet users are not interested in the security field. The tendency of an increase in the number of users on the Internet indicates the need to take preventive measures in order to prevent abuse. In addition to the primary role of parents in this process, it is also necessary to involve teachers 
and society as a whole in order to raise public awareness of risks and dangers (Pešić, 2015, 4-5).

The problem of digital violence was investigated in two primary schools in southeastern Serbia (in the municipality of Niš and the municipality of Gadžin Han), on a sample of 200 students (Marković Krstić and Milošević Radulović, 2014, 525-546). The subject of research was the role of education and upbringing in the safe use of digital technologies within the process of globalization. The occurence and frequency of digital violence among primary school students as well as the role of education and upbringing in its prevention were examined. The initial assumption of this research was that students who are more likely to use digital technologies and who more often use them to socialize, entertain or visit adult sites, or visit and read other people's blogs will be more exposed to the negative impact (in the form of receiving insulting, malicious or threatening messages). In the second segment of the research, it was examined whether students were aware of the possible dangers when using digital technologies and who warned them about different forms of digital violence (parents, brothers/sisters, teachers, school professional team, peer group). The authors' assumption was that greater students' awareness of the dangers/risks to which they are exposed when using digital technologies contributes to their safety when using the Internet and mobile phones. Namely, it follows from the assumption that students who are familiar with the dangers and risks posed by digital technologies will be able to protect themselves more effectively from their negative impact. A special segment of the research was the examination of the form and frequency of electronic violence and whether there was a relation between the sociodemographic characteristics of students (gender, place of residence, grade, students achievement st school) and the accessibility and use of digital technologies (frequency of using the Internet, purpose, knowledge of the dangers, form of digital violence). In the last segment of the research, the frequency of reporting of digital violence, as well as the method of responding (,responses“ to reported violence) of parents, teachers and the school professional team were investigated. Determining their preventive educational activity is an important segment of this research, as it was indirectly possible to determine which subjects were engaged in creating adequate conditions for the safe use of digital technologies, that is where more intense activity in solving this current social problem is required.

Special attention should be paid to the research findings on who warned the students of the dangers of using computers and mobile phones, as it can be seen that parents did that twice more than teachers, while expert teams warn them six times less than their parents. However, significant research findings are that parents were most concerned about the dangers of using computers and mobile phones related to psychophysical health. This can be understood as a result, on one hand, of parental care for the health of their children, but on the other hand, as their insufficient knowledge of other dangers associated with the use of digital technologies. That is why it is necessary to increase the involvement of teachers and members of professional teams of the school (psychologists, pedagogues, sociologists, social workers) in this field of educational activity. It is important to note that students of a village school (Gadžin Han municipality) where there is not a professional school team (only a psychologist) are exposed to digital violence to a greater extent. At the same time they are less familiar with the dangers when using digital technologies in relation to students in a city school (municipality of Niš) in which the expert team consists of all the necessary members. Therefore, the main conclusion of this research is that there is a need for greater educational training and engagement of professional teams in the schools in 
which they were created, as well as their immediate establishment in the schools where they still do not exist for the purpose of a more effective preventive action in the sphere of the safe use of digital technologies (more Marković Krstić and Milošević Radulović, 2014, 545). The results of the research on to whom students would report some form of digital violence also support this claim. Teachers and school professional team again fall significantly behind the parents. This kind of distribution of pupils' responses indicates a lack of communication and understanding in the student - school relationship (the school expert team, teachers), which is another signal that a more effective and immediate intervention in the field of school education is needed.

S. Miladinović, in his work „Children on the Internet and online social networks“, speaks about the necessity of involving all actors of socialization, education and upbringing in solving the problem of digital violence. He emphasizes that the number of children who start relatively risky communication with people they do not know is not negligible and that, therefore, such research findings should be seriously understood by both parents and those who by the nature of their profession have an obligation to care for the youngest generations, for children are clearly unaware of all the possibilities of abuse (2014, 454 ).

Since the forms and frequency of digital violence are multiplying, and its consequences for psycho-physical development and social life of children and young people are getting alarming dimensions, an urgent social intervention in this sphere is necessary. A special role in preventive (educational) activities should be given to teachers and school professional teams, in accordance with their pedagogical and professional competences.

\section{PREVEntion of Digital Violence - The Role of TEACHERS AND SCHOOL PROFESSIONAL TEAMS}

The accelerated development of digital technologies requires more effective protection of children from the risks and threats they face in a virtual space in which they spend a lot of time. Legal regulations in the area of child protection against abuse on the Internet include the Convention on the Rights of the Child 1989 and the Constitution of the Republic of Serbia (more on the legal regulations Čović, 2014, 380-385), but despite this, violence has been widely present for years.

The results of the research on digital violence indicate that children mostly rely on their parents, and only afterwards on the school (teachers and school professional teams) when it comes to the use of digital technologies. However, parents are often insufficiently informed about the dangers their children are exposed to when using digital technologies. The results of the survey (Popadić and Kuzmanović, 2013, 109-128) show that almost half of the interviewed parents consider that they are not sufficiently informed about digital violence, and that almost all of the parents think that the school has the task to get to know them with digital violence and protection measures; more than half of the interviewed parents think that the school should also be strengthened to deal with the problem of digital violence, while more than eighty percent of parents consider that the Internet is still a safer place than the street for their children and young people. The same percentage of parents think that their child is cautious and skilled enough to avoid dangers on the Internet. Such findings show that the role of teachers and professional teams in the prevention of digital violence is of great importance, so that the issue of their professional competences and opportunities for educational activities in this sphere of social life is posed. On the other hand, the results 
of this research show that almost all teachers confirm that it is the school's duty to teach students how to protect themselves from digital violence. It is significant that nearly half of the surveyed teachers think that they are not sufficiently informed about digital violence, and that two-thirds of teachers think that the school does not have enough capacity to deal with this serious problem. This means that, in order to prevent digital violence, digital literacy teachers (digital competence) is necessary, that is teachers have to be educated about how to prepare their students to properly use digital technologies and, of course, develop social skills as well as awareness of non-violent communication, both in real and in the virtual world. Although today there are many definitions of digital literacy, it is common to all that it includes both technical knowledge and skills, as well as critical and creative use of information, solving problems in the digital environment, as well as the safe use of information and communication technology. Digital literacy today is a fundamental life skill, which, on the one hand, allows a person to be realized in numerous life roles, while, on the other hand, marginalizes those who can not access the world of digital information.

It is true that children and young people today use high-tech digital technologies and technically work very well. However, if digital literacy is assessed on the basis of more complex cognitive skills, such as comparing some information and a critical approach to website reliability, then we have a completely different image of the expected one, which is that the digital skills of young people are not at a satisfactory level, that is, young people, regardless of the frequent use of digital technologies, can not be considered digitally literate (Calvani et al., 2012, according to Kuzmanović et al., 2016, 34).

The Strategy for the Development of Education in Serbia recognizes the importance and role of digital technologies for improving the education system by 2020. Accordingly, as well as with the Guidelines for Improving the Role of Information and Communication Technologies in Education, adopted by the National Education Council in December 2013, the Ministry of Education, Science and Technological Development of the Republic of Serbia published the Digital Competences Framework - Digital Age Teacher. Digital competences of teachers are very important, and they include a set of knowledge, skills, attitudes, abilities and strategies necessary for the high quality use of information and communication technologies and digital media (Ferrari 2012, according to Digital Competences Framework, 2017, 5). Several digital competencies of teachers were identified in eight categories: 1) searching for, access, storage and management of information; 2) searching for, adapting and creating digital content for teaching and learning; 3) managing digital content for teaching and learning and sharing it; 4) managing the learning environment; 5) teaching and learning; 6) formative and summative assessment, recording, monitoring and reporting on student progress; 7) communication and cooperation in the online environment; and 8) ethics and security. When it comes to the prevention of digital violence and the safe use of information and communication technology, the importance of the eighth category of teacher competencies can be emphasized, which includes: understanding and adhering to ethical principles and legal norms of safe use of digital content for personal and professional purposes. The teacher is familiar with the basic principles that he should be guided by in order to protect his own data and devices, and he/she is aware of the risks and dangers within the digital environment; he/she is familiar with the data protection measures in the digital environment; he/she is able to store data on various devices regardless of whether they are used for personal or business purposes and he/she is familiar with the rules that allow student safety when in a digital environment - 
security measures against cyber harassment, security regulations and personal data protection, and others (ditto, p. 8).

The competencies of teachers in the field of safe use of digital technologies enable timely recognition of the problem of violence in school and out-of-school environment and the perception of determinants that affect the appearance of its various forms, so that they can significantly contribute to adequate social reaction and intervention and, in particular, to intensifying preventive actions.

The importance of preventive actions of teachers and school professional teams is reflected in the fact that they reduce the possibilities of risky behavior of children and young people. Competent teachers are aware of the fact that digital violence can have lasting consequences on pupils' mental health, socialization, and the quality of interpersonal relationships. Therefore, the cooperation between family, school (teachers, professional teams) and society as a whole is necessary in a comprehensive consideration of this issue, in order to take appropriate preventive activities using positive experiences of other actors.

Preventive activities contribute to raising awareness and sensitivity for recognizing violence and defining measures for protection from violence. The preventive measures of the school are reflected in the formation of moral attitudes and getting familiar with the valid legal norms and sanctions. It's about legal socialization of a person. It is necessary that pupils get to know their civil rights and obligations and to develop responsibility for themselves and the social environment for their own actions, which means they have to be able to coordinate their own activities with existing legislation (behavior in accordance with legal norms). In this way it is possible to educate self-aware and responsible citizens. Responsibility of students is also important for the behavior in the virtual space - the responsibility to protect their data, but also not to abuse someone else's.

In the context of preventive activities, it is very important to explain to students how to protect themselves in situations when they encounter intermittent content or inappropriate offers on the Internet. For physical security, it is necessary to alert students to never leave personal information on the Internet, not to give their location, not to record their codes on a public computer, not to arrange meetings with strangers and always to log out of their account. Psychic security can be achieved by warning students that if they encounter inappropriate and unpleasant content, they immediately close the internet browser and inform an older person about it, not to gossip on the Internet because an internal joke can be accessible to everyone, and in that way, a lot of people can be hurt. It is also important that children understand they are not guilty if they receive messages of disturbing content and become victims of digital violence, and that they should report violence to their parents, teachers and the school professional team. Communication between parents and the school is very important because teachers and school staff can alert parents if there is a change in a pupil's behavior so that parents can react in time. Parents' greater attention and clear rules can contribute to child safety and it will be less likely for the child to come in a potentially dangerous situation (more Marković Krstić and Milošević Radulović, 2014, 542-545).

One of the forms of prevention of violence in our country is the Special Protocol for the Protection of Children and Students from Violence, Abuse and Neglect in Educational Institutions, which contains a system of indicators for identifying phenomena that can potentially lead to violence. The Protocol emphasizes the cause-and-effect relationship between preventive and intervention activities. On the one hand, well-designed, comprehensive preventive activities, based on the principle of involvement of all, reduce the need for intervention activities; on the other hand, consistent implementation of the 
intervention program, with the monitoring of the effects, condition the planning of preventive activities. The protocol also includes information exchange sites - awareness raising, identification of common goals, assessment and monitoring of the situation (more KalezićVignjević et al, 2007).

The prevention of violence is the first level of approach to solving this current social problem. The second level of approach to solving the problem of digital violence is social intervention. Social intervention means a set of actions in situations where some form of violence happened. On the one hand, it facilitates the alleviation of the consequences of violence, with the members of the school professional team (psychologist, pedagogue, sociologist, social worker), teachers and the principal and, on the other hand, it includes continuous work on re-education (psychologist, pedagogue, sociologist and social worker) and punishing the perpetrator of violence (police). The aim is to make it clear that violent behavior is not allowed and that there are clear rules of conduct that must not be violated.

Therefore, education for social responsibility is the starting point for preventing violent behavior, and the intensification of the educational (preventive) activities of schools, teachers and professional teams is one of the possible strategies for solving this significant social problem (eg. editing special websites about digital violence on the school sites, making school boards and posters on the topic of digital violence, watching films about digital violence, organizing interviews with peers, members of the school professional team, parents and representatives of the Ministry of Police on digital violence, organising appropriate activities for the Safe Internet Day which is celebrated every second Tuesday in February in over a hundred countries).

Prevention of digital violence is important on all levels, ranging from an individual through the family, school, state institutions to society as a whole. Despite the intensive use of digital technology, today's children and young people can not be expected to become digitally literate without the support of formal education.

\section{CONCLUSION}

In recent years, there has been a growing debate on the complex social implications of using information and communication technology. Communication through digital technologies provides new experiences, expands aspects and opportunities for acquiring new knowledge, makes information available to a large number of people, but at the same time threatens to radically change human relationships, as well as marginalize those who have no access to the digital world. "Our personal lives have inevitably undergone changes since the forces of globalization penetrated into local contexts, our homes and communities, through impersonal sources - the media, the internet and popular culture. [...] Globalization changes the way we think about ourselves and about our relationship with other people from the root" (Gidens, 2003, 66).

The accelerated development of information and communication technology contributed to global connectivity and intensive communication, as well as to increasing risks and dangers in the digital world. Violence in the virtual space is a phenomenon whose negative consequences are reflected on the individual, as a user of information and communication technology, as well as to his environment and society as a whole. Therefore, the problem of school violence in the process of globalization (more Zdravković, 2010, 180-183), and especially about the problem of digital violence is increasingly publicized which emphasizes the need for its study and research, with the involvement of a large number of experts from 
different scientific fields, in order to find the most efficient ways for adequate preventive action.

The results of empirical research on digital violence indicate that they are manifested in different forms and different intensities, and that primary school students are most exposed to dangers, due to the frequent use of information and communication technology, as well as due to insufficient readiness and lack of knowledge to protect themselves in an adequate way against the possible negative impact. Therefore, the need for greater educational engagement of teachers and professional teams in schools where they were formed, as well as their immediate establishment in schools where they do not exist, is clearly reflected in order to perform better prevention in the sphere of safe use of digital technologies.

Educational activity of the school (teachers and school professional teams) in the field of safe use of digital technologies (the Internet, mobile phones) is more and more necessary because it implies a comprehensive activity of both the school and extracurricular environment in the form of designing, constituting and implementing - active educational strategy. An active educational strategy implies an appropriate social reaction when it comes to the prevention and resolution of problems related to digital violence. It encompasses a range of activities by competent teachers and experts in both school and outof-school environments - from familiarizing students and parents with the dangers that can arise when using digital technology and giving instructions on how to avoid them (editing special pages on the school's website with security topics on the Internet and digital violence, getting familiar with digital violence through texts in school magazines, making school boards, watching spots/movies about digital violence followed by suitable conversation; making short videos taking into account the privacy of the data and the photos used with the necessary parental consen for the child to participate in the activity, organizing interviews, peer training, tribunes and workshops, inviting representatives of the Police Service to the school to talk about security on the internet) - via providing professional assistance in acquiring knowledge in information technology and using computer programs for blocking and filtering spam; advising students not to respond to provocative and offensive messages; alleviating emotional reactions of students; helping students break the "chain" of violence and counseling to change their mobile phone number and e-mail address; counseling students to preserve information relevant to the investigation and reporting violence to the police - to evaluating the effects of preventive measures (forms and frequency of violence after the implementation of measures).

Regardless of the fact that digital violence is not exclusively related to the school environment and that many people believe that it is not the school task or duty to deal with the problem of digital violence, it is indisputable that teachers and school professional teams play an extremely important role, both in education and upbringing, in prevention and solving the problem of digital violence. This, among other things, is confirmed by the Law on the Basis of the Education System and the Special Protocol for the Protection of Children and Students against Violence, Abuse and Neglect in Educational Institutions, which are obligatory in character for all educational institutions. The key role of the school (teachers and professional teams) is legally prescribed when it comes to protecting students from all forms of violence.

Note: Prepared within the framework of the Project Tradition, Modernization and National Identity in Serbia and the Balkans in the European Integration Process (179074D), implemented by the Center for Sociological Research at the Faculty of Philosophy in Nis, financed by the Ministry of Education, Science and Technological Development of the Republic of Serbia. 


\section{REFERENCES}

Čović, A. (2014). Načini zloupotrebe dece putem interneta [Ways to abuse children via the Internet]. In D. Todorović et al. (Eds.), Internet $i$ društvo [Internet and Society], (pp. 379-393). Niš/Beograd: Srpsko sociološko društvo, Beograd; Filozofski fakultet, Niš; Institut za uporedno pravo, Beograd.

Gidens, A. (2003). Sociologija [Sociology]. Beograd: Ekonomski fakultet.

Kalezić-Vignjević, A. et al. (2007). Posebni protokol za zaštitu dece i učenika od nasilja, zlostavljanja $i$ zanemarivanja u obrazovno-vaspitnim ustanovama [Special Protocol for the Protection of Children and Students against Violence, Abuse and Neglect in Educational Institutions]. Beograd: Ministarstvo prosvete Republike Srbije.

Kuzmanović, D. et al. (2016). Digitalno nasilje - prevencija i reagovanje [Digital Violence - Prevention and Reaction]. Beograd: Ministarstvo prosvete, nauke i tehnološkog razvoja, Pedagoško društvo Srbije i UNICEF.

Marković Krstić, S. \& Milošević Radulović, L. (2014). Vaspitanje i obrazovanje u funkciji bezbednog korišćenja novih tehnologija u procesu globalizacije [Education in the function of safe use of new technologies in the process of globalization]. In B. Dimitrijević (Eds.) Savremene paradigme u nauci i naučnoj fantastici, Nauka $i$ savremeni univerzitet 3 [Contemporary paradigms in science and science fiction, Science and Contemporary University 3], (pp. 525-546). Niš: Filozofski fakultet, Univerzitet u Nišu.

Miladinović S. (2014). Deca na internetu i onlajn društvenim mrežama [Children on the Internet and online social networks]. In D. Todorović et al. (Eds.), Internet $i$ društvo [Internet and Society] (pp. 443-457). Niš/Beograd: Srpsko sociološko društvo, Beograd; Filozofski fakultet, Niš; Institut za uporedno pravo, Beograd.

Olweus, D. (1998). Nasilje među djecom u školi [Violence among children at school]. Zagreb: Školska knjiga.

Okvir digitalnih kompetencija - Nastavnik za digitalno doba [Digital Competence Framework - Digital Age Teacher]. Beograd: Ministarstvo prosvete, nauke i tehnološkog razvoja (uz podršku British council). Retrieved December 20, 2017 from http://www.mpn.gov.rs/wp-content/uploads/2017/04/Okvir-digitalnihkompetencija-Final-1.pdf.

Popadić, D. \& Kuzmanović, D. (2013). Korišćenje digitalne tehnologije, rizici i zastupljenost digitalnog nasilja među učenicima u Srbiji [The use of digital technology, the risks and the representation of digital violence among students in Serbia]. Beograd: Ministarstvo prosvete, nauke i tehnološkog razvoja, UNICEF, Telenor.

Pešić, A. (2015). Obrazovanje kao prevencija elektronskom nasilju [Education as a Prevention of Electronic Violence]. Retrieved December 15, 2017 from http://www.ftn.kg.ac.rs/download/SIR/SIR\%20Andrijana $\% 20$ Pesic.pdf.

Ristić, D., Cizelj Pajvančić A. \& Marinković, D. (2014). Mapiranje društvene geografije interneta: značenja, materijalnost, moć [Mapping the Social Geography of the Internet: Meaning, Materiality, Power]. In D. Todorović et al. (Eds.), Internet $i$ društvo [Internet and Society], (pp. 23-29). Niš/Beograd: Srpsko sociološko društvo, Beograd; Filozofski fakultet, Niš; Institut za uporedno pravo, Beograd.

Spalević, Ž. (2013). Karakterizacija psihološkog zlostavljanja u Cyber prostoru [Characterization of Psychological Abuse in Cyber Space]. Retrieved September 30, 2013 from http://www.infoteh.rs.ba/ zbornik/2013/radovi/RSS-3/RSS-3-9.pdf.

Škrlec, N., Buljan Flander \& Kralj, D. (2010). Nasilje modernim oblicima komunikacije - mobitel - prikaz slučaja [Violence against modern forms of communication - case report]. In V. Kolesarić (Eds.), Nasilje nad djecom i među djecom [Violence against children and among children], (pp. 665-670). Osijek: Filozofski fakultet.

Zdravković, D. (2010). Global education: education for peace and the suppression of violence [Globalno obrazovanje: obrazovanje za mir i suzbijanje nasilja]. In Didactica Slovenica - Pedagoška obzorja 2, pp. $170-184$.

Zakon o osnovama sistema vaspitanja i obrazovanja [The Law on the Foundations of the Education System], „Službeni glasnik RS“, No. 88 (2017). 


\section{ULOGA NASTAVNIKA I STRUČNIH TIMOVA ŠKOLE U PREVENCIJI DIGITALNOG NASILJA}

U radu se razmatra uloga nastavnika i stručnih timova škole u prevenciji digitalnog nasilja radi povećanja bezbednosti učenika prilikom korišćenja informaciono-komunikacione tehnologije. Škola kao središte vaspitno-obrazovnog procesa može svojim kontinuiranim delovanjem ukazivati na moguće rizike u funkcionisanju i korišćenju informaciono-komunikacione tehnologije, kao i na druge ključne činioce prevencije digitalnog nasilničkog ponašanja i društvene intervencije kada do nasilja dođe. Društvena reakcija na digitalno nasilje podrazumeva primenu aktivne vaspitno-obrazovne strategije škole, koja uključuje sticanje znanja o rizicima i rizičnom ponašanju i razvijanje odgovornost pojedinca prilikom korišćenja digitalnih tehnologija, zatim strategiju delovanja kada je pojedinac izložen nekom obliku digitalnog nasilja i sankcije za one koji krše pravila. Poslednjih godina učestale su inicijative naučnika $i$ stručnjaka za teorijskim $i$ empirijskim istraživanjima u sferi digitalnog nasilja u cilju sticanja znanja $i$ podizanja svesti o opasnostima koje prete u virtuelnom okruženju. Takve inicijative mogu značajno doprineti intenziviranju vaspitno-obrazovnog delovanja škole (nastavnika i stručnih timova) ukazivanjem na njihovu nezamenljivu ulogu i značaj u koncipiranju adekvatnih preventivnih strategija za rešavanje ovog značajnog društvenog problema.

Ključne reči: digitalno nasilje, prevencija, nastavnik, stručni tim škole, aktivna vaspitno-obrazovna strategija. 